\title{
Thymic Stromal Lymphopoietin Contributes to Myeloid Hyperplasia and Increased Immunoglobulins, But Not Epidermal Hyperplasia, in RabGEF1-Deficient Mice
}

\author{
Mindy Tsai, ${ }^{*}$ Ching-Cheng Chen, ${ }^{*}$ Kaori Mukai, ${ }^{*}$ \\ Chang Ho Song, ${ }^{*}$ Lucas J. Thompson, ${ }^{\dagger}$ \\ Steven F. Ziegler, ${ }^{\dagger}$ See-Ying Tam, ${ }^{*}$ \\ and Stephen J. Galli ${ }^{* \neq}$ \\ From the Departments of Pathology, * and Microbiology and \\ Immunology, Stanford University School of Medicine, Stanford, \\ California; and the Immunology Program, ${ }^{\dagger}$ Benaroya Research \\ Institute, Seattle, Washington
}

Mice overexpressing the proallergic cytokine thymic stromal lymphopoietin (TSLP) in the skin develop a pathology resembling atopic dermatitis. RabGEF1, a guanine nucleotide exchange factor for Rab5 GTPase, is a negative regulator of IgE-dependent mast cell activation, and Rabgef1 $1^{-/-}$and TSLP transgenic mice share many similar phenotypic characteristics, including elevated serum IgE levels and severe skin inflammation, with infiltrates of both lymphocytes and eosinophils. We report here that Rabgef1 ${ }^{-/-}$ mice also develop splenomegaly, lymphadenopathy, myeloid hyperplasia, and high levels of TSLP. Rabgef1 ${ }^{-/-}$TSLPR ${ }^{-/-}$mice, which lack TSLP/TSLP receptor (TSLPR) signaling, had levels of blood neutrophils, spleen myeloid cells, and serum IL-4, IgG1, and IgE levels that were significantly reduced compared with those in Rabgef1 ${ }^{-/-}$TSLPR ${ }^{+/+}$mice. However, Rabgef1 ${ }^{-/-}$TSLPR ${ }^{-/-}$mice, like Rag1- or eosinophildeficient Rabgef1 ${ }^{-/-}$mice, developed cutaneous inflammation and epidermal hyperplasia. Therefore, in Rabgef1 ${ }^{-/-}$mice, TSLP/TSLPR interactions are not required for the development of epidermal hyperplasia but contribute to the striking myeloid hyperplasia and overproduction of immunoglobulins observed in these animals. Our study shows that RabGEF1 can negatively regulate TSLP production in vivo and that excessive production of TSLP contributes to many of the phenotypic abnormalities in Rabgef1 $1^{-/-}$mice. However, the marked epidermal hyperplasia, cutaneous inflammation, and increased numbers of dermal mast cells associated with RabGEF1 deficiency can develop via a TSLPR-independent pathway, as well as in the absence of Rag1 or eosinophils. (Am J Pathol 2010, 177:2411-2420; DOI: 10.2353/ajpath.2010.100181)

Thymic stromal lymphopoietin (TSLP) is an interleukin (IL)7-like cytokine initially identified as a growth and differentiation factor for lymphocytes, and later implicated as an important regulator of allergic inflammation. ${ }^{1-5}$ TSLP binds to the TSLP receptor complex, which consists of an IL-7 receptor $\alpha$ chain (IL-7R $\alpha$ ) and a TSLP receptor (TSLPR) chain. ${ }^{1-3}$ TSLPR is an atypical type I cytokine receptor that binds TSLP with low affinity, but the binding affinity with TSLP is markedly enhanced when TSLPR is incorporated into the heterodimeric IL-7R $\alpha /$ TSLPR receptor complex. ${ }^{5}$ TSLP treatment results in the expansion and maturation of human myeloid dendritic cells and the induction of OX4OL expression in these cells. ${ }^{3,6}$ TSLP-treated myeloid dendritic cells can promote inflammatory responses by inducing OX40-OX40L-dependent Th2 cytokine production in naïve CD4 $T$ cells and by secreting chemokines that recruit Th2 cells and granulocytes. ${ }^{3,7,8}$ Moreover, TSLP can induce mast cells to produce Th2 cytokines independently of IgE stimulation. ${ }^{9}$ Recently, TSLP has been shown to promote survival, cytokine and chemokine release, and up-regula-

Supported by United States Public Health Service grants (S.J.G.) Al23990, Al070813, and CA72074. C.H.S. was supported by the CBNU funds for overseas research.

Accepted for publication July 14, 2010

Supplemental material for this article can be found on http://ajp. amjpathol.org

S.J.G. occasionally consults for companies that sell and/or are developing agents to treat allergic disorders, including Amgen Inc., Genentech, and Novartis and is a member of the Scientific Advisory Board of Tunitas Therapeutics, which is developing protein therapeutics for the treatment of allergic diseases.

Current address of C.-C.C.: City of Hope Medical Center, Stem Cell and Leukemia Research, Duarte, California; of C.H.S.: Department of Anatomy, Chonbuk National University Medical School, Jeonju, Korea.

Address reprint requests to Stephen J. Galli, M.D., or Mindy Tsai, D.M.Sc., Stanford University School of Medicine, Department of Pathology, L-235, 300 Pasteur Drive, Stanford, CA 94305-5324. E-mail: sgalli@stanford.edu or mindyt@stanford.edu. 
tion of adhesion molecules in human eosinophils. ${ }^{10}$ These observations suggest that TSLP can orchestrate allergic inflammation by activating cells of both the adaptive and the innate immune systems. In accord with this notion, transgenic mice expressing TSLP under the regulation of the keratinocyte-specific promoters for keratin-14 ${ }^{11}$ or keratin$5^{12}$ develop atopic dermatitis-like skin lesions, with inflammatory infiltrates including eosinophils and lymphocytes, and also exhibit pronounced splenomegaly, lymphadenopathy, and elevated serum levels of IgE and IgG1 antibodies. ${ }^{11,12}$ In addition to the development of a disorder resembling atopic dermatitis, mice that overproduce TSLP in the skin are also more susceptible to antigen induced airway inflammation and hyperresponsiveness, suggesting that TSLP contributes to the so-called "atopic march" which is hypothesized to link atopic dermatitis with the later onset of asthma. ${ }^{13,14}$

The mouse ortholog of RabGEF1 (also known as Rabex-5, Rabaptin-5 associated exchange factor for Rab5) was first identified in a survey of differentially expressed mRNA transcripts in mouse mast cells activated by aggregation of high affinity IgE receptors (FceRI). ${ }^{15}$ RabGEF1deficient (Rabgef $1^{-I}$ ) mast cells exhibit delayed receptor internalization, elevated and prolonged intracellular signaling events, and enhanced cytokine and mediator release in response to FceRl- or Kit-dependent activation. ${ }^{15-17}$ In addition to its role as a negative regulator of mast cell activation, RabGEF1 can contribute to intracellular vesicular trafficking by catalyzing the conversion of GDP to GTP on members of the Rab5 family of small GTPases, molecules known to be important for early endosome fusion during receptor internalization and for endocytic vesicular trafficking. ${ }^{18-20}$

We previously reported that deletion of RabGEF1 protein in the mouse results in substantial morbidity, including skin lesions characterized by marked epidermal hyperplasia and hyperkeratosis, infiltration of lymphocytes, eosinophils, and other inflammatory cells, and increased numbers of dermal mast cells. ${ }^{15}$ Also, the serum of RabGEF1-deficeint mice contains high concentrations of IgE and histamine. ${ }^{15}$ Notably, phenotypic abnormalities very similar to those of Rabgef1 ${ }^{-1-}$ mice also have been observed in transgenic mice which overexpress TSLP in the skin. ${ }^{11,12}$ In this study, we show that Rabgef1 $1^{-1-}$ mice exhibit markedly elevated levels of TSLP and IL-4, develop splenomegaly, lymphadenopathy, and expansion of myeloid cells in the blood, bone marrow, and spleen, and produce large numbers of B cells in the spleen. To investigate the contribution of TSLP to the dermatitis and other aspects of the pathology of Rabgef $1^{-1-}$ mice, we disrupted TSLP signaling in these mice by breeding Rabgef1 $1^{+/-}$mice with TSLP receptor-deficient $\left(T S L P R^{-1-}\right)$ mice, which lack expression of TSLPR and are unresponsive to TSLP. ${ }^{21}$ Our data indicate that TSLPR-mediated signaling contributes substantially to the development of myeloid hyperplasia, splenomegaly, and high levels of serum IL-4, IgE, and IgG1 in Rabgef1 ${ }^{-1-}$ mice. By contrast, we show that the spontaneous cutaneous inflammation, increased numbers of dermal mast cells, and marked epidermal hyperplasia and hyperkeratosis observed in Rabgef1 ${ }^{-1-}$ mice can occur in the absence of TSLPR-mediated signaling, as well as in Rabgef1 ${ }^{-1-}$ mice which lack mature lymphocytes or eosinophils.

\section{Materials and Methods}

\section{Mice}

Rabgef1 ${ }^{-1-}$ mice on a mixed C57BL/6 and 129/SvEv genetic background ${ }^{15}$ were backcrossed to C57BL/6J or BALB/cJ mice for at least 10 generations. No live Rabgef1 ${ }^{-1-}$ pups have ever been obtained on the C57BL/6 strain, whereas $\sim 19 \%$ of the two-week-old pups of BALB/c Rabgef1 ${ }^{+/-}$parents were identified as RabGEF1 knock-outs. We created (C57BL/6 $\times$ BALB/C)F 1 RabGEF1-deficient mutants by mating C57BL/6-Rabgef1 ${ }^{+/-}$and BALB/CRabgef1 ${ }^{+/-}$mice; $\sim 12 \%$ of the two-week-old (C57BL/6 $\times$ $\mathrm{BALB} / \mathrm{c}) \mathrm{F}_{1}$ pups were genotyped as RabGEF1 knockouts. Like 129/B6-Rabgef1-1- mice, all BALB/C or $(\mathrm{C} 57 \mathrm{BL} / 6 \times \mathrm{BALB} / \mathrm{c}) \mathrm{F}_{1}$ Rabgef1 $^{-1-}$ mice spontaneously developed severe dermatitis. Skin lesions were clearly visible at $\sim 3$ weeks after birth when the mice were weaned. However, (C57BL/6 $\times$ BALB/C)F $F_{1}$-Rabgef1 ${ }^{-1-}$ mice developed skin lesions and signs of morbidity more

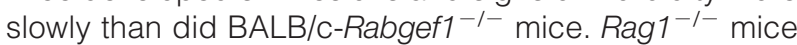

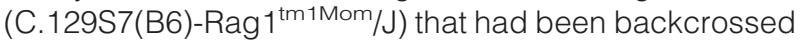
to Balb/cAnNTac for seven generations and eosinophildeficient GATA1 ${ }^{\Delta d b /}$ mice (C.Cg-Gata1 $1^{\text {tm6Sho} / J) ~ t h a t ~ h a d ~}$ been backcrossed to BALB/c for eight generations were obtained from the Jackson Laboratory (Bar Harbor, ME). TSLP receptor-deficient $\left(T S L P R^{-1-}\right.$ ) mice on BALB/C background ${ }^{21}$ were bred in our facility. Fcer1a ${ }^{-1-}$ mice 22 on the BALB/c background were kindly provided by J.-P. Kinet at Harvard School of Medicine. Rag1 ${ }^{-1-}$, Fcer1a ${ }^{-1-}$, TSLPR $^{-1-}$, and GATA1 ${ }^{\triangle d b l}$ mice were mated to BALB/c-Rabgef1 ${ }^{+/-}$mice to generate single or double mutant mice.

All animal care and experimentation were conducted in compliance with current National Institutes of Health guidelines and with the approval of the Stanford University Institutional Animal Care and Use Committee.

\section{Flow Cytometry}

Cells were blocked with unconjugated anti-CD16/CD32 on ice for 10 minutes and then stained with PE-labeled anti-Gr-1 (RB6-8C5, $0.3 \mu \mathrm{g} / \mathrm{ml}$ ), FITC-labeled anti-Mac-1 (M1/70, $2.5 \mu \mathrm{g} / \mathrm{ml}$ ), and PE-labeled anti-B220 (RA3-6B2, $1 \mu \mathrm{g} / \mathrm{ml}$ ) antibodies (BD Biosciences, San Jose, CA). The expression of cell surface markers was analyzed on a FACSCaliber (BD Biosciences) using FlowJo Software (version 8.7.1). Dead cells (stained with 7-aminoactinomycin D (Sigma, St. Louis, MO) or propidium iodide (PI; Invitrogen, Carlsbad, CA) were not included in the analyses.

\section{Peripheral Blood and Bone Marrow Leukocyte Counts}

Numbers of total leukocytes, neutrophils, monocytes, and lymphocytes in heparinized blood were quantified using the Abbott Cell-Dyn 3500 automated hematology analyzer. We quantified nucleated bone marrow cells recovered from two femora plus two tibiae per mouse. 


\section{Histology and Immunohistochemistry}

Formalin-fixed tissues were embedded in paraffin, and 4- $\mu \mathrm{m}$ tissue sections were stained with hematoxylin and eosin or with $0.1 \%$ (vol/vol) toluidine blue (LabChem, Inc., Pittsburgh, PA), pH 1.0 (for detection of mast cells). To quantify eosinophils, paraffin-embedded skin sections were stained with Congo red (Sigma-Aldrich, St. Louis, $\mathrm{MO})$ as previously described. ${ }^{23}$ Numbers of dermal mast cells or eosinophils were counted in 8-12 consecutive microscopic fields. Epidermal thickness and numbers of mast cells or eosinophils per horizontal ear cartilage field length $(\mathrm{mm})$ or per $\mathrm{mm}^{2}$ abdominal skin area were quantified using Image-Pro Plus Version 6.0 software (Media Cybernetics, Bethesda, MD).

For localization of TSLP protein, skin sections were incubated with goat anti-mouse TSLP antibody $(2 \mu \mathrm{g} / \mathrm{ml}$, R\&D Systems, Minneapolis, MN) or with normal goat IgG (R\&D Systems), at $4^{\circ} \mathrm{C}$ for 42 hours, washed, and with biotinylated rabbit-anti-goat IgG for 30 minutes at room temperature. After incubating with $\mathrm{ABC}$ solution (Vector Laboratories, Burlingame, CA) for 30 minutes at room temperature, positive staining was detected by DAB (3,3'-diaminobenzidine; Sigma-Aldrich) and sections were counterstained with Meyer's hematoxylin. For detection of a keratinocyte marker, a mouse anti-human keratin monoclonal antibody (AE1/AE3) (LifeSpan BioSciences, Seattle, WA), that has reactivity to the 19 known human epidermal keratins and can also react with mouse tissue, was used to stain cytokeratin using a Vector ${ }^{R}$ M.O.M. detection kit (Vector Laboratories, Inc. Burlingame, CA).

\section{ELISA}

A single-cell suspension of splenocytes was prepared by mechanical disaggregation of the whole spleen, and red blood cells were lysed in RBC lysing buffer (Sigma-Aldrich, St. Louis, MO). Ear skin, spleen, and splenocyte lysates were prepared by sonicating the tissuses in Tper EDTA-free lysis buffer (Pierce, Rockford, IL) containing protease inhibitors (Roche, Indianapolis, IN), and total protein concentrations in the supernatants were measured by a Bio-Rad Dc protein assay (Bio-Rad Laboratories, Hercules, CA) as in ref. ${ }^{24}$ Concentrations of TSLP protein in serum, cell, or tissue lysates were measured by ELISA (R\&D Systems). Serum IL-4 was measured by ELISA (BD Biosciences). Total serum IgE and IgG1 titers were measured by ELISA as described. ${ }^{24}$

\section{MPO Assay}

$100 \mu \mathrm{l}$ MPO substrate buffer $(50 \mathrm{mmol} / \mathrm{L}$ phosphate buffer $\mathrm{pH} 6.0,0.05 \%$ [vol/vol] $\mathrm{H}_{2} \mathrm{O}_{2}$ [Sigma-Aldrich, St. Louis, MO], $0.4 \mathrm{mg} / \mathrm{ml}$ o-phenylenediamine dihydrochloride [OPD tablets; Sigma-Aldrich]) was added to $50 \mu \mathrm{l}$ of the diluted supernatants of ear skin or spleen lysates (prepared as described above) or to recombinant MPO (CalBiochem, Gibbstown, NJ) used as the standard protein. After 5 to 10 minutes, $50 \mu \mathrm{l} 1 \mathrm{~N} \mathrm{HCl}$ was added to stop the reaction, and OD was measured by a plate reader.

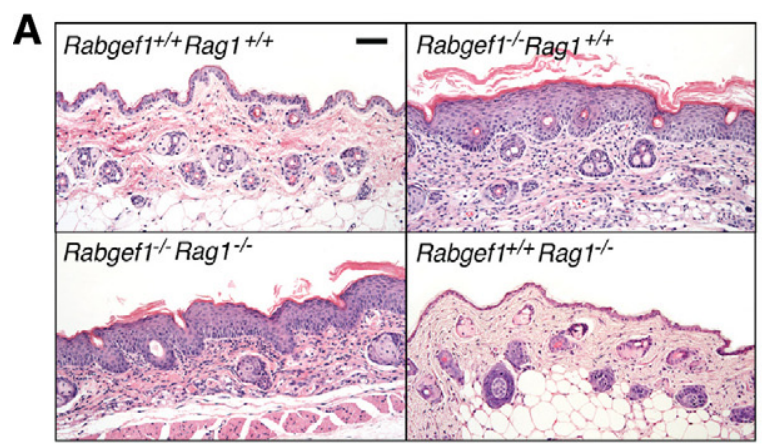

D

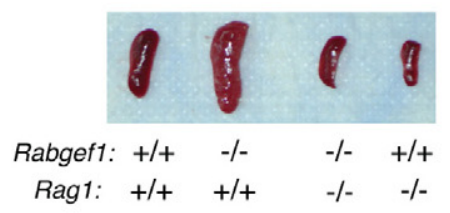

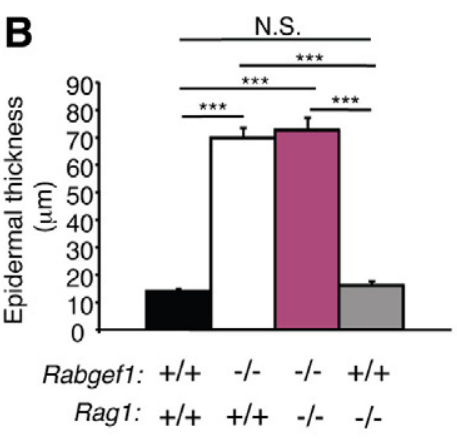

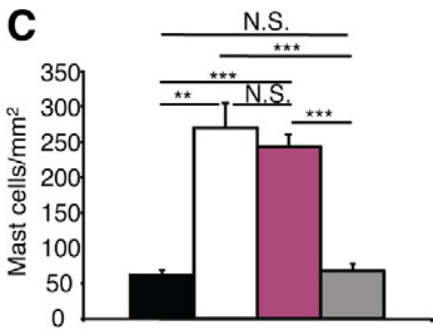

Rabgef1: $+/+\quad-/-\quad-/-\quad+/+$ Rag1: $+/++/+-/-\quad-/-$

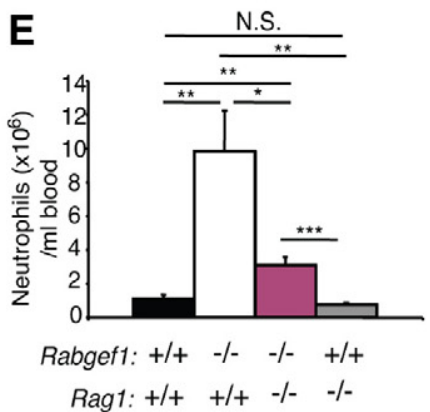

Figure 1. Variable Rag1-dependence of different phenotypic abnormalities in Rabgef1 $1^{-/-}$mice. Rabgef $1^{+/-}$mice were bred with Rag $1^{-/-}$mice to generate Rag1-deficient Rabgef1 $1^{+/-}$mice, and mice with each of the four possible genotypes were analyzed. A: Representative microscopic images of histological sections of abdominal skin stained with hematoxylin and eosin; Scale bar $=50 \mu \mathrm{m}$. Epidermal thickness $(\mathbf{B})$ and mast cell numbers $(\mathbf{C})$ in the dermis of abdominal skin D: Gross images and weight (as the percentage of body weight) of the spleens (E). Numbers of neutrophils in the peripheral blood. All mice were of the BALB/c strain and 4-5 weeks old. Data shown are the mean + SEM from three to eight mice for histological analysis of the skin, from seven to 15 mice for assessment of spleen weights, and from seven to 10 mice for neutrophil counts in the blood. ${ }^{*} P<0.05,{ }^{* * *} P<0.01$, **** $P<0.001 ;$ N.S., not significant $(P>0.05)$. 


\section{Statistics}

Results represent means \pm or + SEM. Differences between results were assessed for statistical significance by the unpaired Student's $t$-test, 2-tailed.

\section{Results}

\section{Rabgef1 $1^{-/-}$Mice Develop Myeloid Hyperplasia} and Expansion of B Lymphocytes in the Spleen

We found that, in addition to developing severe dermatitis and elevated serum IgE levels, ${ }^{15}$ Rabgef1 ${ }^{-1-}$ mice developed splenomegaly and markedly enlarged lymph nodes (see Supplemental Figure S1A at http://ajp.amjpathol.org). Rabgef1 ${ }^{-1-}$ mice also developed significant increases in numbers of neutrophils and/or monocytes in the spleen (see Supplemental Figure S1B at http://ajp.amjpathol.org), bone marrow (see Supplemental FigureS1C athttp://ajp.amjpathol. org), and peripheral blood (see Supplemental Figure S1D at http://ajp.amjpathol.org) of these mice. In addition to the changes observed in the myeloid compartment, the num- bers of B lymphocytes were substantially increased in the spleen but were significantly lower in the bone marrow of Rabgef1 ${ }^{-1-}$ mice compared to those in the wild-type mice (see Supplemental Figure S1E at $h$ ttp://ajp.amjpathol.org). Thus, deletion of RabGEF1 expression resulted in an expansion of myeloid cells in the blood, spleen, and bone marrow, and abnormal B lymphopoiesis, with significant increases in B cell numbers in the spleen.

\section{Role of Adaptive Immunity in the Development of the Phenotypic Abnormalities of Rabgef1 ${ }^{-1-}$ Mice}

To assess whether adaptive immunity contributed to the development of spontaneous dermatitis, epidermal hypersplasia, increased numbers of dermal mast cells, and other pathology in RabGEF1-deficient mice, we generated Rabgef1 ${ }^{-1-}$ Rag $1^{-1-}$ mice by breeding RabGEF1 mutant mice with $R a g 1^{-1-}$ mice, which can't produce mature lymphocytes because of their inability to undergo $V(D) J$ recombination of immunoglobulin and T cell receptor genes. ${ }^{25} \mathrm{~A}$ lack of Rag1 had no significant effect on epidermal thickness, epidermal hyperkeratosis, or dermal mast cell num-
A

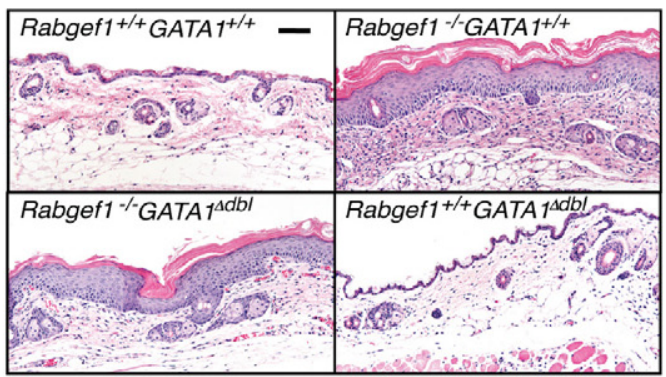

D

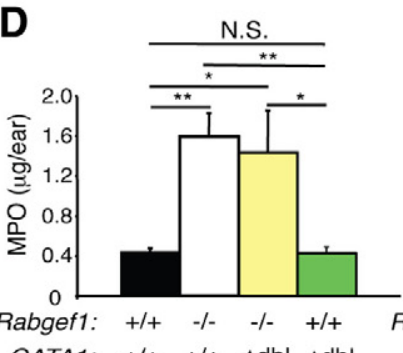

GATA1: $+/++/+\Delta \mathrm{dbl} \Delta \mathrm{dbl}$

E

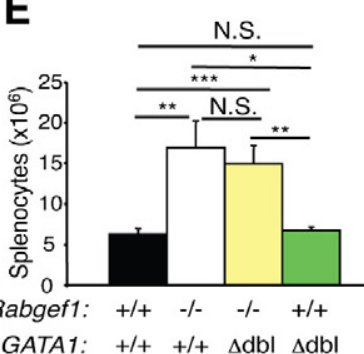

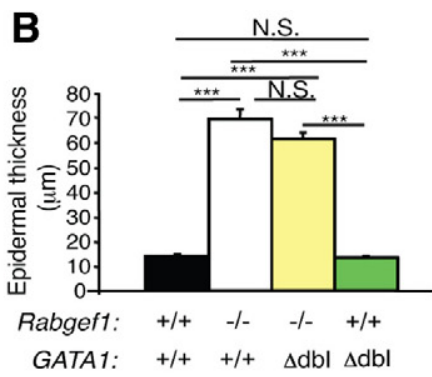
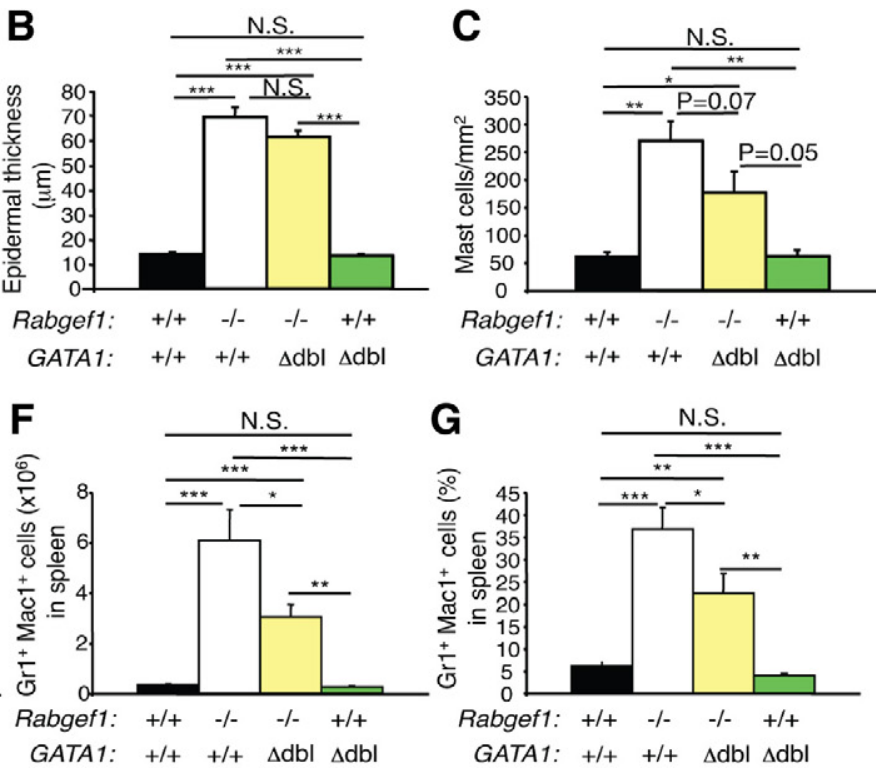

H

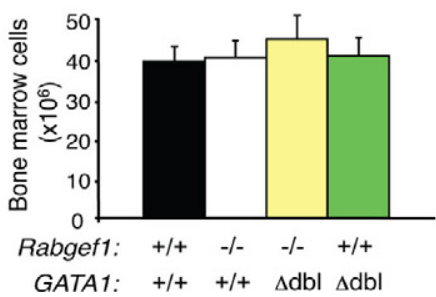

I

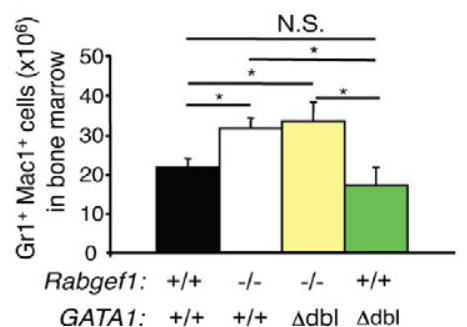

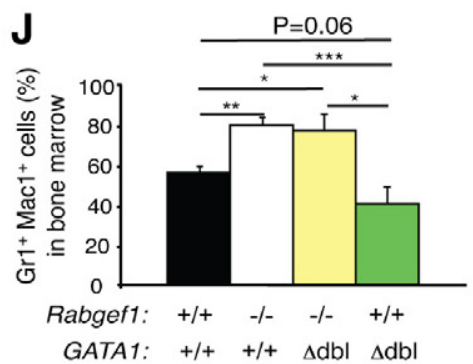

Figure 2. Development of skin pathology and expansion of myeloid cells in eosinophil-deficient Rabgef1 ${ }^{-/-}$mice. Rabgef1 ${ }^{+/-}$mice were bred with GATA1 $1^{\Delta d b /}$ mice to generate eosinophil-deficient Rabgef $1^{+/}$mice, and mice with each of the four possible genotypes were analyzed. A: Representative microscopic images of histological sections of abdominal skin stained with hematoxylin and eosin; Scale bar $=50 \mu \mathrm{m}$. Epidermal thickness (B) and mast cell numbers $(\mathbf{C})$ in the dermis of abdominal skin. D: Myeloperoxidase (MPO) levels in the ear skin. E: Total leukocyte numbers in the spleen. F and $\mathbf{G}$ : Numbers (F) and percentages (G) of $\mathrm{Gr}^{+} \mathrm{Mac}^{+}$cells in the spleen, as assessed by flow cytometry. H: Total leukocyte numbers in the bone marrow. I and $\mathbf{J}$ : Numbers $(\mathbf{I})$ and $\%(\mathbf{J})$ of $\mathrm{Gr} 1^{+} \mathrm{Mac} 1^{+}$ cells in the bone marrow, as assessed by flow cytometry. All mice were of the BALB/c strain and $4-6$ weeks old. Data shown are the mean + SEM from three to eight mice per group for analyses of the skin, from six to nine mice per group for analyses of the spleen, and from five to nine mice per group for analyses of the bone marrow. ${ }^{*} P<0.05,{ }^{* * *} P<0.01,{ }^{* * * *} P<0.001$; N.S., not significant $(P>0.05)$. 
bers in Rabgef1-1- mice (Figure 1, A-C). However, Rabgef1 $1^{-1-}$ Rag $1^{-1-}$ spleens were notably smaller than Rabgef1 $1^{-l-} \mathrm{Rag}^{+/+}$spleens and also slightly but significantly smaller than the spleens of the corresponding wildtype mice (Figure 1D). Both Rabgef1 $1^{-1-}$ Rag $1^{-1-}$ and Rabgef1 $1^{-/}$Rag $^{+/+}$mice exhibited increased neutrophil numbers in the blood compared to those observed in the wild-type mice, but numbers of circulating neutrophils in

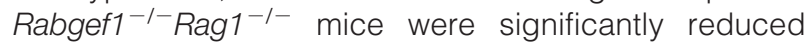
compared to those of Rabgef1 $1^{-/-}$Rag $1^{+/+}$mice (Figure $1 \mathrm{E})$. These data indicate that while adaptive immunity is not essential for the development of aspects of skin pathology in Rabgef1-l- mice, it does contribute to the development of lymphohematopoietic abnormalities in these animals. Our results also show that the high levels of IgE and IgG1 immunoglobulin production in Rabgef1 $1^{-1-}$

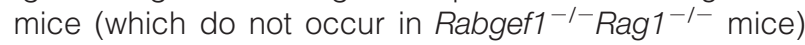
do not contribute significantly to the development of the assessed aspects of animals' skin pathology. In accord

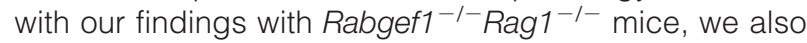
found that Rabgef1 $1^{-1-}$ mice which lack the $\alpha$ chain of the $\mathrm{F}_{\mathrm{C} \varepsilon \mathrm{R}} \mathrm{I}^{22}$ (the $\mathrm{IgE}$ binding component of the high affinity IgE receptor complex) and thus are unable to respond to FCeRI-dependent cell activation, exhibit skin pathology

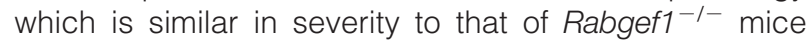
expressing the wild-type $\mathrm{F} c \varepsilon \mathrm{Rl} \alpha$ chain (see Supplemental Figure S2, A-D at http://ajp.amjpathol.org).

\section{Eosinophils Are Not Required for Epidermal Hyperplasia or Myeloid Hyperplasia in Rabgef1 $1^{-1-}$ Mice}

We found extensive eosinophil infiltration in the skin, bone marrow, spleen, lymph nodes, stomach, and liver of Rabgef1 ${ }^{-1-}$ mice (see Supplemental Figure S3A at http://ajp.amjpathol.org and unpublished data). To assess the role of eosinophils in the phenotypic abnormalities of RabGEF1-deficient mice, we generated eosinophil-deficient

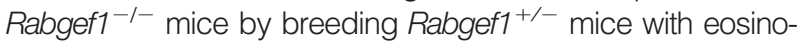
phil-deficient GATA1 ${ }^{\Delta d b l}$ mice. ${ }^{26}$ Rabgef1 ${ }^{-1-}$ GATA ${ }^{\Delta d b l}$ and Rabgef1 ${ }^{-1-} \mathrm{GATA1}^{+/+}$mice exhibited very similar increases in epidermal thickness and hyperkeratosis (Figure 2, A and B). Although there was a slight $(\sim 34 \%)$ reduction in mast cell numbers in the inflamed abdominal skin of Rabgef1 ${ }^{-1-}$ GATA1 ${ }^{\Delta a b l}$ mice compared to values for Rabgef1 ${ }^{-1-}$ GATA $1^{+/+}$mice $(P=0.07$ by unpaired Student's $t$-test) (Figure $2 C$ ), mast cell numbers in the inflamed ear skin of

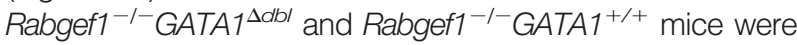
very similar (see Supplemental Figure S3B at $h$ ttp://ajp. amjpathol.org). MPO levels in the ear skin were also very

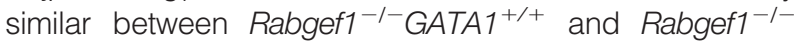
GATA1 ${ }^{\Delta d b l}$ mice and were highly elevated in Rabgef1 ${ }^{-1-}$

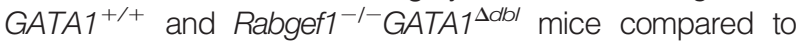
those in the wild-type or Rabgef1 ${ }^{+/+}$GATA $1^{\Delta d b l}$ mice (Figure

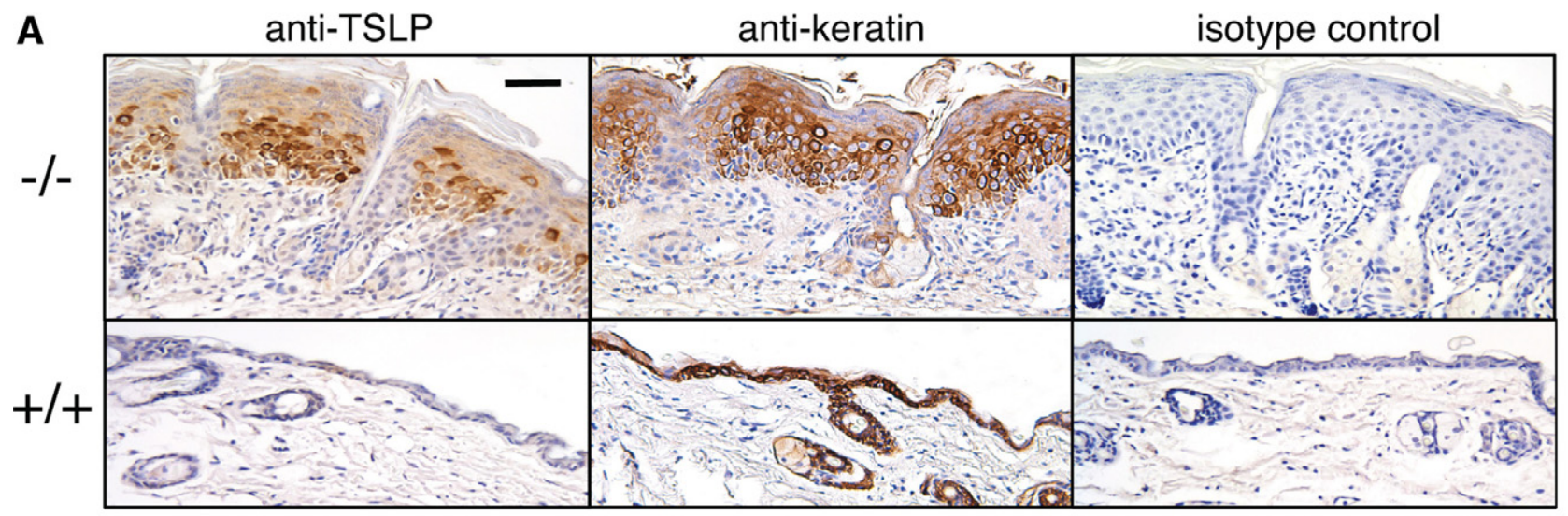

B
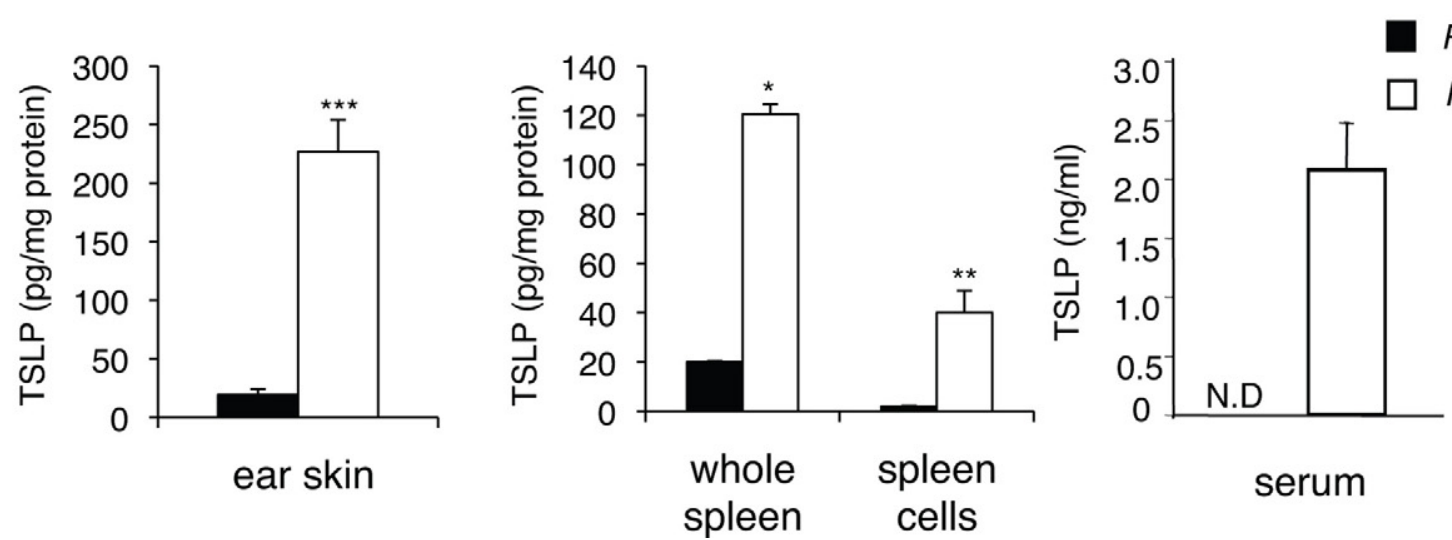

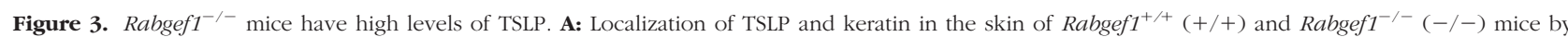
immunohistochemistry; Scale bar $=50 \mu \mathrm{m}$. B: Concentrations of TSLP protein in ear skin, whole spleens, splenocytes, and serum of Rabgef $1^{+/+}$and Rabgef $1^{-/-}$ mice by ELISA. Data shown in $\mathbf{B}$ are the mean + SEM from five to seven mice per group. All mice were of the BALB/c strain and $4-6$ weeks old. ${ }^{*} P<0.05$, ** $P<$ $0.01,{ }^{* * * *} P<0.001$ versus Rabgef $1^{+/+}$controls. N.D., not detectable. 


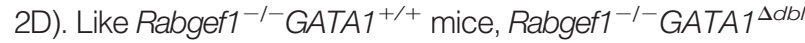
mice exhibited enlarged spleens (Figure 2E), as well as expansion of $\mathrm{Gr}_{1}{ }^{+} \mathrm{Mac}_{1}{ }^{+}$cells in the spleen (Figure 2, $\mathrm{F}$ and $\mathrm{G}$ ) and bone marrow (Figure 2, $\mathrm{H}-\mathrm{J}$ ). The numbers and $\%$ of $\mathrm{Gr}_{1}{ }^{+} \mathrm{Mac}^{+}$cells in the spleen of Rabgef1 ${ }^{-1-}$ GATA $1^{\Delta d b l}$ mice were reduced compared to those in Rabgef1 $1^{-/-}$GATA $1^{+/+}$mice, probably largely reflecting the absence of eosinophils in such animals (Figure 2, $F$ and $\mathrm{G})$. However, there were no detectable differences in the numbers and \% of $\mathrm{Gr} 1^{+} \mathrm{Mac} 1^{+}$cells in the bone

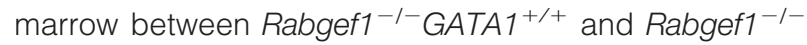
GATA $1^{\Delta d b /}$ mice (Figure 2, I and J). Moreover, the periph-

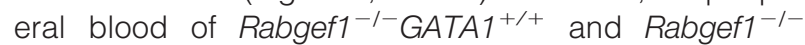
GATA1 ${ }^{\Delta d b l}$ mice exhibited similar levels of WBC, neutrophilia and lymphopenia (see Supplemental Figure S4, A-E at http://ajp.amjpathol.org). Taken together, these data indicate that eosinophils are not required for the development of epidermal hyperplasia, myeloid hyperplasia, blood neutrophilia, or blood lymphopenia in Rabgef $1^{-1-}$ mice, and that, depending on the anatomical site, eosinophils make little or no contribution to the increased numbers of dermal mast cells in the skin lesions of these animals.

\section{TSLPR-Dependent Signaling Is Not Required for Epidermal Hyperplasia in Rabgef1 ${ }^{-1-}$ Mice}

The targeted overexpression of TSLP in keratinocytes in mice results in an atopic dermatitis-like skin disease accompanied by massive lymphadenopathy and splenomegaly, ${ }^{11,12}$ increased numbers of eosinophils, ${ }^{11,12}$ elevated serum IgE levels, ${ }^{11,12}$ myeloid hyperplasia, ${ }^{11,12}$ and abnormal B lymphogenesis. ${ }^{27}$ Similar to Rabgef1 ${ }^{-1-}$ mice, the keratinocyte-specific TSLP transgenic mice develop skin disease that occurs with minimal contribution of T or B lymphocytes. ${ }^{12}$ We detected strikingly elevated levels of TSLP in Rabgef1- $1^{--}$mice in keratinocytes (by immunohistochemistry), and in the ear skin, whole spleen, splenocytes, and serum (by ELISA) (Figure 3, A and $B$ ), raising the possibility that TSLP contributes to the development of pathology in these animals. To test this hypothesis, we bred Rabgef1 ${ }^{+/-}$mice with TSLP receptor-deficient (TSLPR ${ }^{-1-}$ ) mice ${ }^{21}$ to disrupt the signaling pathway mediated by TSLPR in these animals.

Rabgef1 ${ }^{-1-} T_{S L P R}{ }^{-1-}$ mice were grossly indistinguishable from Rabgef1 ${ }^{-1-}$ TSLPR $^{+/+}$mice (see Supplemental Figure S5A at http://ajp.amjpathol.org). Both Rabgef1 ${ }^{-1-}$ TSLPR $^{-1-}$ and Rabgef1 ${ }^{-1-}$ TSLPR $^{+/+}$mice were smaller than the wildtype or Rabgef $1^{+/+}$TSLPR $^{-/-}$mice and developed prominent skin lesions (see Supplemental Figure S5, A and B at http://ajp.amjpathol.org). Like Rabgef1 ${ }^{-1-} \mathrm{TSLPR}^{+/+}$ mice, Rabgef1 ${ }^{-I}$ TSLPR $^{-1-}$ mice also exhibited high concentrations of serum TSLP (see Supplemental Figure S5C at $h t t p: / /$ ajp.amjpathol.org). Histological analysis of the skin lesions in Rabgef1 ${ }^{-1-} \mathrm{TSLPR}^{+/+}$and Rabgef1 $1^{-1-} \mathrm{TSLPR}^{-/-}$mice showed comparable levels of epidermal hyperplasia and hyperkeratosis in their skin lesions (Figure 4A). These observations were confirmed by morphometric measurements

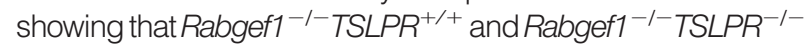
mice developed skin lesions with similar increases in epidermal thickness (Figure 4B and see Supplemental Figure S5D at $h$ ttp://ajp.amjpathol.org) and dermal mast cell numbers (Figure 4C and see Supplemental Figure S5E at $h t t p: / /$ ajp.amjpathol.org), whether cutaneous lesions were sampled from ear pinnae (Supplemental Figure S5, D and E at http://ajp.amjpathol.org) or abdominal skin (Figure 4, B and C). On the other hand, numbers of eosinophils in the dermis of Rabgef1 $1^{-1-}$ TSLPR $^{-1-}$ skin were reduced to approximately the wild-type levels (see Supplemental Figure S3A at http://ajp.amjpathol.org), suggesting that TSLPR may regu-
A

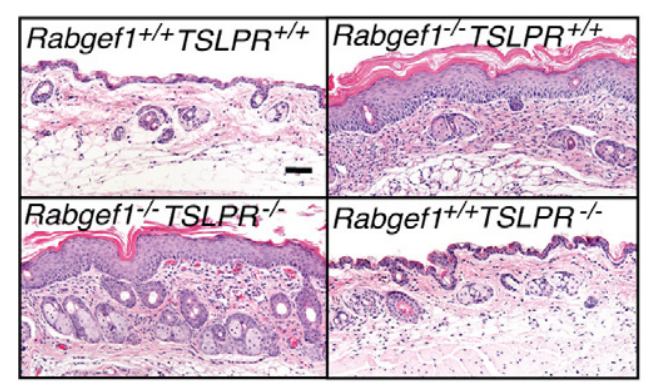

C

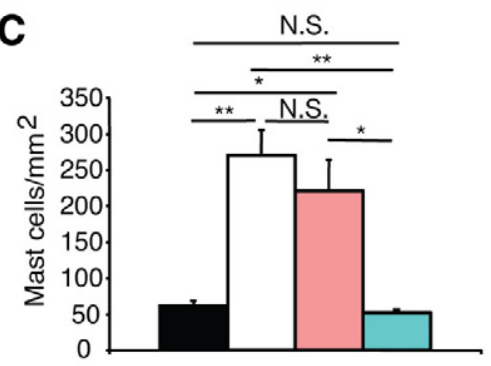

Rabgef1: $+/+\quad-/-\quad-/-\quad+/+$

TSLPR: $+/++/+-/-\quad-/-$

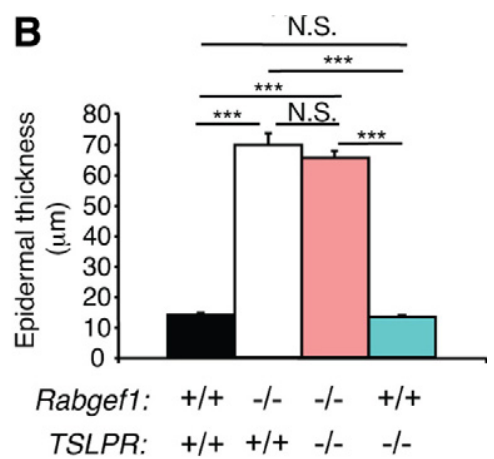

D

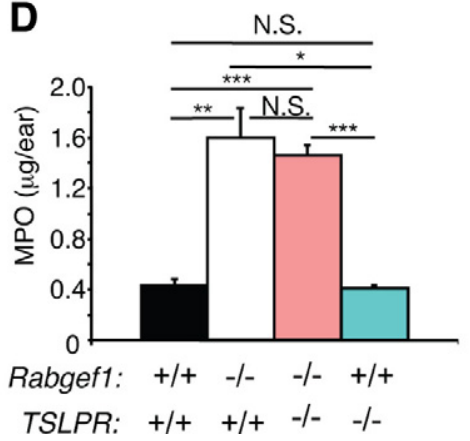

Figure 4. TSLPR-independent development of skin pathology in Rabgef $1^{-/-}$mice. A: Representative microscopic images of abdominal skin sections of Rabgef1 $1^{+/+}$TSLPR $^{+/+}$(wild type), Rabgef1 $^{-1-}$ TSLPR $^{+/+}, \quad$ Rabgef1 $1^{-/-}$TSLPR $^{-/-}$ and Rabgef1 $1^{+/+}$TSLPR $^{-/-}$mice. Sections were stained with hematoxylin and eosin; Scale bar = $50 \mu \mathrm{m}$. Images of skin of Rabgef $1^{+/+}$TSLPR $^{+/+}$ and Rabgef $1^{-/-}$TSLPR ${ }^{+/+}$mice are identical to those labeled Rabgef1 $1^{+/+}$GATA1 $^{+/+}$and Rabgef $1^{-/-}$GATA1 $^{+/+}$in Figure $2 \mathrm{~A}$, because these images represent the same genotypes in these figures (ie, wild-type mice and mice deficient only in RabGEF1). Epidermal thickness (B) and mast cell numbers $(\mathbf{C})$ in the dermis of abdominal skin. D: Myeloperoxidase (MPO) levels in the ear skin. All mice were of the BALB/C strain and 4-6 weeks old. Data shown are the mean + SEM from three to eight mice per group. ${ }^{*} P<0.05,{ }^{* * *} P<0.01,{ }^{* * * *} P<0.001 ;$ N.S., not significant $(P>0.05)$. 
A

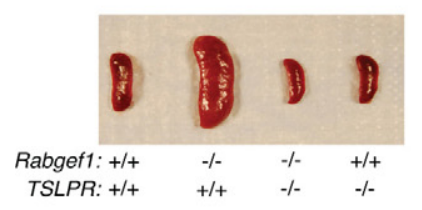

E
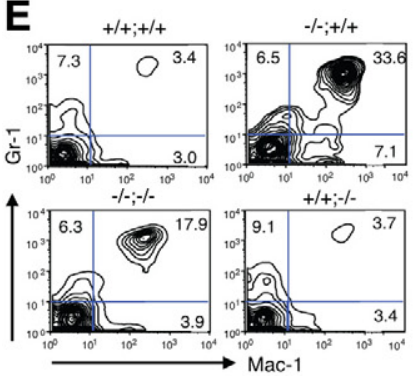

I

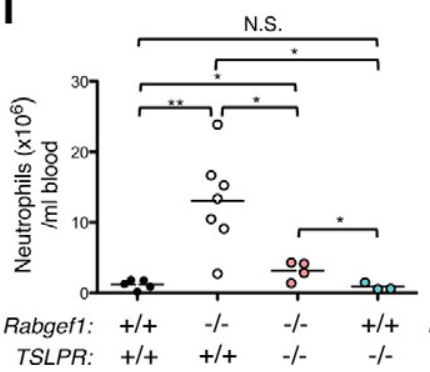

B

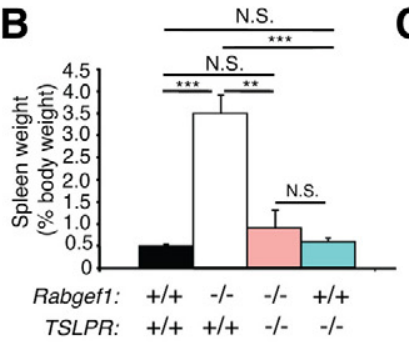

$\mathbf{F}$

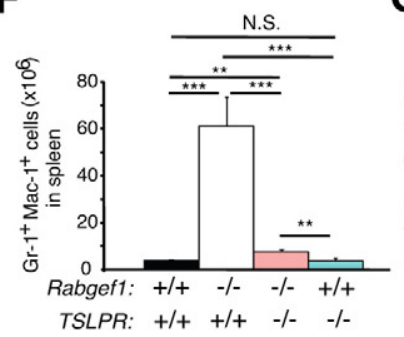

C

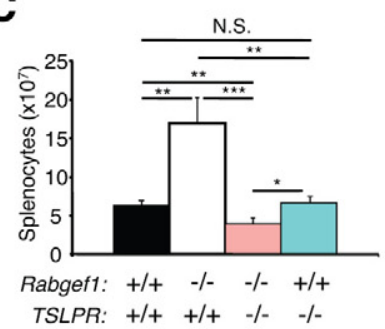

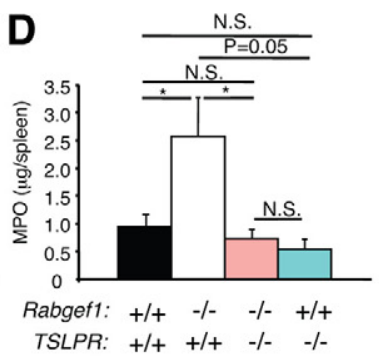

H
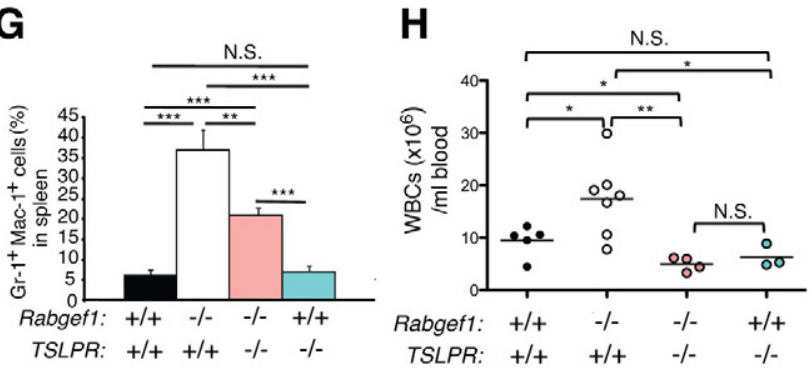

J

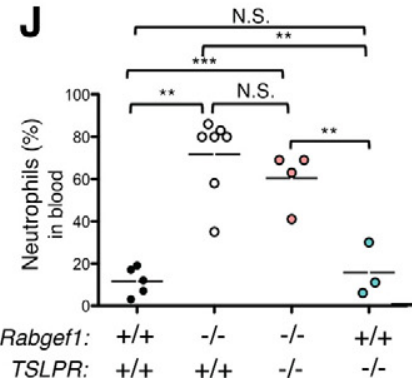

$\mathbf{K}$

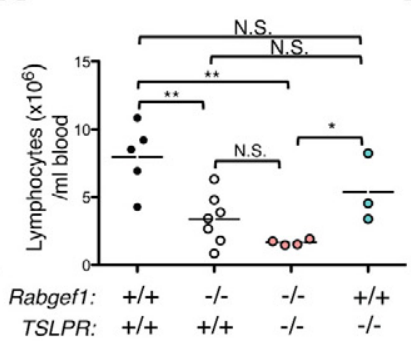

$\mathbf{L}$

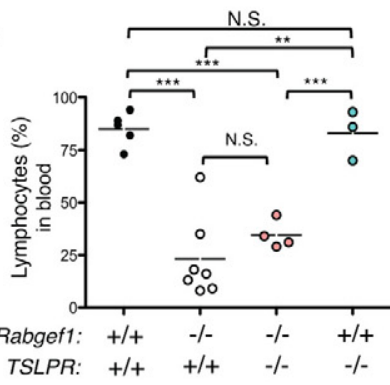

Figure 5. TSLPR contributes to myeloid hyperplasia and elevated blood neutrophils in Rabgef1 ${ }^{-/-}$mice. A: Gross images of spleens of $R a b g e f 1^{+/+}$TSLPR ${ }^{+/+}$

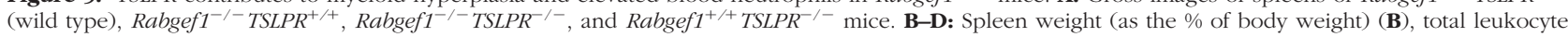
numbers (C), and myeloperoxidase (MPO) levels (D). E: Representative FACS profiles of spleen cells stained with anti-Gr1 and anti-Mac1 antibodies in

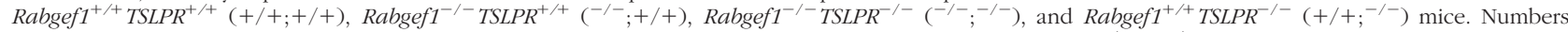
shown in each quadrant are percentages of total viable spleen cells. F and $\mathbf{G}$ : Numbers (F) and \% $(\mathbf{G})$ of $\mathrm{Gr} 1^{+}$Mac1 ${ }^{+}$cells in the spleens analyzed by flow cytometry. H-L: Total white blood cells (WBCs) (H), and numbers (I and $\mathbf{K}$ ) and \% ( $\mathbf{J}$ and $\mathbf{L}$ ) of neutrophils (I and $\mathbf{J})$ and lymphocytes (K and $\mathbf{L})$ in the peripheral blood. All mice were of the BALB/c strain and 4-6 weeks old. Data shown are from four to 12 mice per group for analyses of spleens and three to seven mice per group for analyses of blood. Horizontal bars indicate mean values. ${ }^{*} P<0.05,{ }^{* *} P<0.01,{ }^{* * * * *} P<0.001 ;$ N.S., not significant $(P>0.05)$.

late the recruitment and/or survival of this granulocyte in the skin of Rabgef1-l- mice. Myeloperoxidase (MPO) activity, an index for myeloid cell infiltration, ${ }^{28}$ measured in the ear skin was substantially higher in both Rabgef1 ${ }^{-1-} T S L P R^{+/+}$ and Rabgef1 $1^{-1-}$ TSLPR ${ }^{-1-}$ mice than in the wild-type or Rabgef1 ${ }^{+/+}$TSLPR $^{-/-}$mice, but was similar between Rabgef1 ${ }^{-1-}$ TSLPR $^{+/+}$and Rabgef1 ${ }^{-/-}$TSLPR $^{-1-}$ mice (Figure 4D). Taken together, our results show that TSLPR-dependent signaling is dispensable for the development of some aspects of the skin pathology in Rabgef1 $1^{-1-}$ mice, such as the epidermal hyperplasia and hyperkeratosis, and the increases in numbers of dermal mast cells and dermal content of MPO.

\section{TSLPR-Dependent Signaling Promotes Myeloid Hyperplasia and Increased Numbers of B Cells in the Spleen, and Elevated Levels of Serum IL-4, IgE, in Rabgef1 ${ }^{-/-}$Mice}

In contrast to the development of skin lesions in RabGEF1-deficient mice, which was largely TSLPR-independent, spleens of Rabgef1-/- $T S L P R^{-/-}$mice were signif- icantly smaller than those of Rabgef1-1- $T S L P R^{+/+}$mice, even when corrected for body weight (Figure 5, A and B), and were also slightly smaller (Figure 5A) and contained significantly fewer cells (Figure $5 \mathrm{C}$ ) than those of the corresponding wild-type or Rabgef1 ${ }^{+/+} T S L P R^{-1-}$ mice. The MPO levels in Rabgef1-1- $T S L P R^{-1-}$ spleens were likewise reduced to levels observed in the wild-type and Rabgef1 $1^{+/+}$TSLPR $^{-/-}$spleens (Figure 5D). Furthermore, the numbers and $\%$ of $\mathrm{Gr}_{1}{ }^{+} \mathrm{Mac} 1^{+}$cells in the spleens of Rabgef1 ${ }^{-1-}$ TSLPR $^{-1-}$ mice (Figure 5, E-G) were markedly reduced compared to those in Rabgef1 ${ }^{-1-}$ TSLPR ${ }^{+/+}$ spleens but still slightly but significantly higher than those in wild-type or Rabgef1 $1^{+/+} T_{S L P R}{ }^{-/-}$mice (Figure 5, E-G). By contrast, the numbers and \% of $\mathrm{Gr}^{+} \mathrm{Mac}^{+}$cells in the bone marrow were similar between Rabgef1 ${ }^{-1-} T S L P R^{-1-}$ and Rabgef1 ${ }^{-1-} \mathrm{TSLPR}^{+/+}$mice and were significantly higher than those in wild-type or Rabgef1 ${ }^{+/+} T S L P R^{-/-}$mice (see Supplemental Figure S6 at $h$ ttp://ajp.amjpathol.org).

Analyses of peripheral blood leukocytes revealed findings similar to those obtained in the spleen. Numbers of white blood cells (WBCs) and neutrophils in the peripheral blood of Rabgef1 ${ }^{-/-}$TSLPR $^{+/+}$mice were highly elevated compared to those in the wild-type, Rabgef1-1-TSLPR ${ }^{-1-}$, or 
A

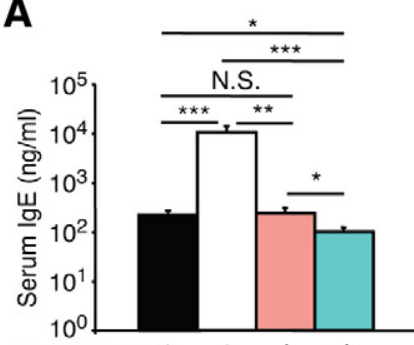

Rabgef1: $+/+\quad-/-\quad-/-\quad+/+$

TSLPR: +/+ +/+ -/- -/-
C

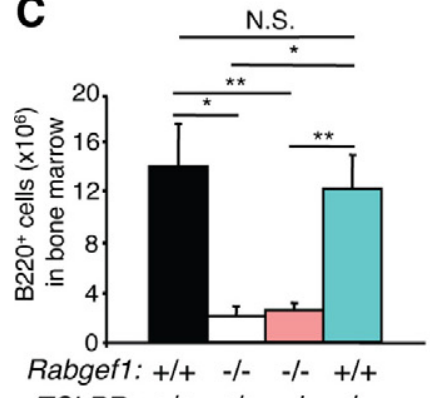

TSLPR: +/+ +/+ -/- -/-
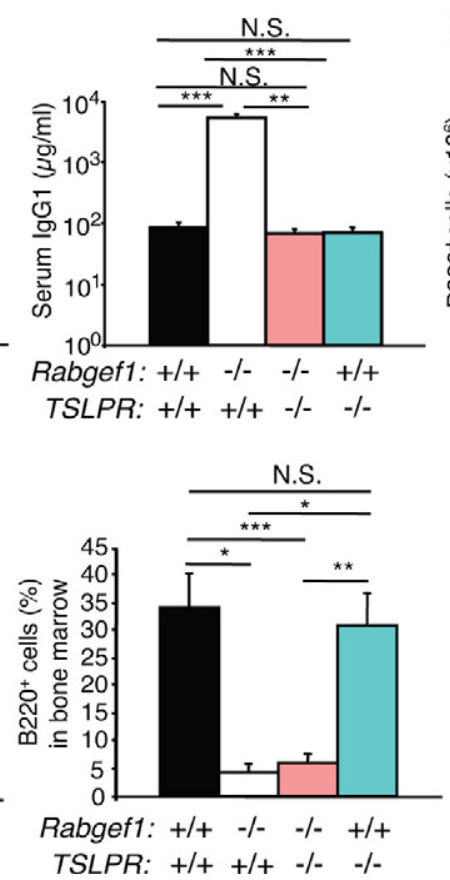

B

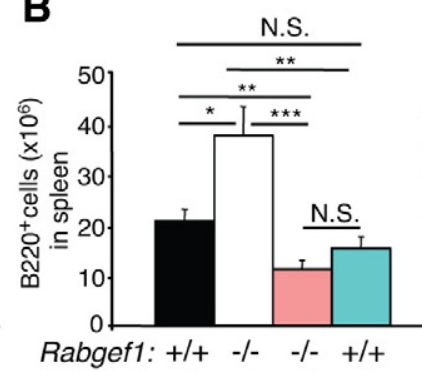

TSLPR: +/+ +/+ -/- -/-

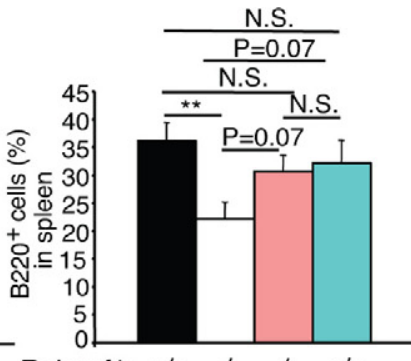

Rabgef1: $+/+\quad-/-\quad-/-\quad+/+$

TSLPR: +/+ +/+ -/- -/-

D

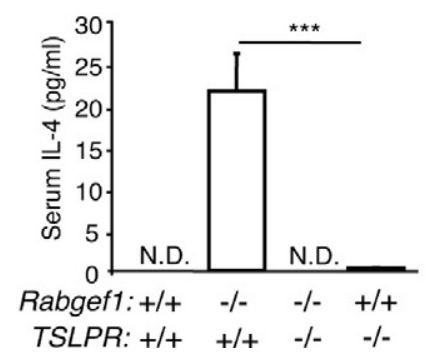

Figure 6. TSLPR contributes to increases in serum IgE and IgG1, splenic B cells, and serum IL-4 levels in Rabgef1 ${ }^{-/-}$mice. A: Concentrations of serum IgE and IgG1. B: Numbers and percentages of B220 ${ }^{+}$cells in the spleen, as assessed by flow cytometry. C: Numbers and percentages of B220 ${ }^{+}$cells in the bone marrow, as assessed by flow cytometry. D: Concentrations of serum IL-4. Data shown are the mean + SEM from four to 15 mice per group for analyses of serum immunoglobulins, from three to seven mice per group for quantification of B220 ${ }^{+}$cells, and from nine to 14 mice per group for measurement of serum IL-4. N.D., not detectable. All mice were of the BALB/c strain and $4-6$ weeks old. ${ }^{*} P<0.05,{ }^{* *} P<0.01,{ }^{* * * *} P<0.001$; N.S., not significant $(P>0.05)$.

Rabgef1 ${ }^{+/+}$TSLPR $^{-/-}$mice (Figure 5, $\mathrm{H}$ and I). Rabgef1 ${ }^{-1-}$ TSLPR $^{-1-}$ mice exhibited much reduced numbers of blood WBCs and neutrophils compared to Rabgef1 ${ }^{-1-} \mathrm{TSLPR}^{+/+}$mice (Figure 5, $\mathrm{H}$ and I), but the numbers and \% of neutrophils in Rabgef $1^{-1-}$ TSLPR $^{-1-}$ blood were still elevated significantly compared to values for the peripheral blood of the wild-type or Rabgef1 ${ }^{+/+} T_{S L P R}{ }^{-/-}$mice (Figure $5,1$ and $J)$. The slight increase in numbers of blood neutrophils in Rabgef1 ${ }^{-1-}$ TSLPR $^{-1-}$ mice may have reflected the myeloid hyperplasia in the bone marrow of these animals (see Supplemental Figure S6, A-C at $h$ ttp://ajp.amjpathol.org). Notably, Rabgef1 ${ }^{-1-}$ TSLPR $^{+/+}$and Rabgef1 ${ }^{-1-}$ TSLPR $^{-1-}$ mice exhibited similar numbers and \% of peripheral blood lymphocytes, values which were lower than those in the wild-type or Rabgef1 ${ }^{+/+}$TSLPR ${ }^{-/-}$mice (Figure 5, $\mathrm{K}$ and L). These results indicate that, in Rabgef1-l- mice, TSLP/TSLPR interactions can enhance myeloid cell production in the spleen and result in higher levels of neutrophils in the peripheral blood but are not required for the marked lymphopenia in the peripheral blood.

We next evaluated whether TSLP/TSLPR interactions influenced immunoglobulin (lg) production or aspects of B cell development in RabGEF1-deficient mice. In contrast to the markedly increased concentrations of serum IgG1 and IgE detected in Rabgef1 $1^{-1-} T S L P R^{+/+}$mice, levels of IgG1 and IgE in Rabgef1 ${ }^{-1-} T_{S L P R^{-1-}}$ mice were very similar to those in wild-type mice (Figure 6A). However, we detected a significant reduction in total serum IgE concentrations in Rabgef1 ${ }^{+/+} T S L P R^{-/-}$mice $(100.7 \pm 21.9 \mathrm{ng} / \mathrm{ml})$ compared to those in the wild-type $(224.8 \pm 41.4 \mathrm{ng} / \mathrm{ml})$ or Rabgef1 ${ }^{-1-}$ TSLPR $^{-1-}(243.6 \pm$ $64.0 \mathrm{ng} / \mathrm{ml}$ ) mice. The numbers of $\mathrm{B}^{2} 2 \mathrm{O}^{+}$cells in the spleen of Rabgef1-1- TSLPR $^{-1-}$ mice were substantially reduced compared to those in Rabgef1 ${ }^{-1-}$ TSLPR $^{+/+}$ spleen and slightly but significantly reduced compared to those in the spleen of the wild-type mice (Figure 6B). However, disruption of TSLPR-mediated signaling in Rabgef1 ${ }^{-/-}$ mice did not appear to alter the \% or numbers of $\mathrm{B}_{2} 2 \mathrm{O}^{+}$ cells in the bone marrow, as Rabgef1 $1^{-1-}$ TSLPR $^{+/+}$and Rabgef1-l- TSLPR $^{-1-}$ mice exhibited similar levels of $\mathrm{B}_{22}{ }^{+}$cell deficiency in the bone marrow (Figure 6C).

TSLP has been shown to induce IL-4 production in CD4 ${ }^{+} \mathrm{T}$ cells and to promote Th2 lymphocyte differentiation in the absence of exogenous IL-4 and antigen-presenting cells. ${ }^{29,30}$ We detected strikingly increased concentrations of IL-4 in the serum of Rabgef1 ${ }^{-1-}$ TSLPR $^{+/+}$mice (Figure 6D). However, IL-4 was not or only barely detectable in the serum of wild-type, Rabgef1 ${ }^{-/-}$TSLPR $^{-/-}$, and Rabgef1 $1^{+/+}$ $T_{S L P R}{ }^{-1-}$ mice (Figure 6D). These results indicate that the striking increase in serum IL-4 levels observed in RabGEF1deficient mice is largely dependent on TSLPR-mediated signaling and suggest that TSLPR-dependent enhancement of IL-4 production may contribute to the markedly increased numbers of splenic B cells and serum IgE and IgG1 concentrations in Rabgef1 ${ }^{-1-}$ mice.

\section{Discussion}

We found that Rabgef1 $1^{-1-}$ mice exhibited markedly elevated serum and tissue concentrations of TSLP, indicating that RabGEF1 is a negative regulator of TSLP levels in vivo. We do not know whether RabGEF1 has this effect through direct or indirect mechanisms, but it is known 
that epithelia of the skin, intestine, and respiratory tract are the major sources of TSLP ${ }^{3}$ and that production of TSLP in these epithelial cells can be induced by active vitamin $\mathrm{D}_{3}\left(1 \mathrm{a}, 25-(\mathrm{OH})_{2} \mathrm{D}_{3}\right)$ or its low calcemic analog, ${ }^{31}$ proinflammatory cytokines, ${ }^{32-35}$ and various TLR ligands. ${ }^{33,35}$ In addition, bone marrow-derived cells, including human mast cells ${ }^{36}$ and mouse basophils, ${ }^{37}$ also can produce TSLP. While current understanding of the mechanisms regulating TSLP production is rather limited, $\mathrm{NF}-\kappa \mathrm{B}-$ binding sites are present in the promoters of both human and mouse TSLP genes, ${ }^{35}$ and there is evidence supporting an involvement of NF- $\kappa \mathrm{B}$ pathways in the regulation of TSLP production. ${ }^{33-35,38}$ RabGEF1 has been shown to be a potent inhibitor of NF- $\kappa \mathrm{B}$-dependent signaling. ${ }^{39}$ Therefore, in Rabgef1 $1^{-/-}$mice, it is possible that enhancement of NF- $\kappa \mathrm{B}-$ dependent signaling may contribute to the overproduction of TSLP in keratinocytes and perhaps other TSLP-producing cells.

TSLP has been strongly implicated in the pathogenesis of human atopic dermatitis and in some mouse models of atopic dermatitis. ${ }^{4,40,41}$ Many of the phenotypic abnormalities observed in Rabgef1 $1^{-1-}$ and keratinocyte-specific TSLP transgenic mice can also be detected in $\operatorname{RXR} \alpha \beta^{\text {ep-I- }}$ mice, that have keratinocyte-specific ablation of the retinoid $X$ receptors, ${ }^{11}$ and each of these three types of mutant mice expresses high levels of TSLP in the skin. In addition, in a mouse model of atopic dermatitis elicited by repeated epicutaneous sensitization with ovalbumin, $T S L P R^{-/-}$mice express markedly decreased eosinophil infiltration, and levels of Th2 cytokines, in the skin. ${ }^{42}$ Finally, patients with atopic dermatitis express copious amount of TSLP in their skin lesions. ${ }^{7}$ Such observations in human subjects, together with those obtained with TSLP transgenic or TSLPR ${ }^{-/-}$mice, have strongly implicated TSLP in the development of allergic skin inflammation.

However, our finding that Rabgef1 $1^{-1-} T S L P R^{-/-}$mice which are incapable of responding to TSLP stimulation continued to exhibit skin lesions with some features of atopic dermatitis (including epidermal hypersplasia, dermal inflammation, and increased numbers of dermal mast cells) points to the existence of a TSLP/TSLPR-independent mechanism for the development of cutaneous epidermal hyperplasia and chronic inflammation, at least in mice. Notably, we showed that chronic skin lesions with substantial epidermal hyperplasia and increased numbers of dermal mast cells can also develop in Rabgef1 ${ }^{-1-}$ mice which lack Rag1 or eosinophils. By contrast, the skin pathology elicited by exogenous administration of TSLP required the presence of T cells and eosinophils. ${ }^{43}$ Taken together, our findings indicate that Rabgef1 ${ }^{-1-}$ mice develop chronic inflammation of the skin with increased levels of MPO in the dermis, increased numbers of dermal mast cells, and epidermal hyperplasia by a robust mechanism that does not require the participation of TSLP/ TSLPR-depending signaling, adaptive immunity or eosinophils. By contrast, we found that TSLP/TSLPR-dependent signaling was required for the increased numbers of eosniophils observed in the skin lesions of Rabgef1 ${ }^{-1-}$ mice, and it is possible that TSLP/TSLPR-dependent signaling also may influence the recruitment, survival, and/or func- tional activation of other subsets of leukocytes in the skin lesions of Rabgef1 ${ }^{-l-}$ mice.

Although TSLPR was not essential for the development of cutaneous inflammation, epidermal hypersplasia, or increased numbers of mast cells in the skin lesions of Rabgef1 ${ }^{-1-}$ mice, other striking phenotypic abnormalities of Rabgef $1^{-1-}$ mice, including splenic myeloid cell expansion, abnormal B cell development, and enhanced serum levels of IL-4 and IgE and IgG1 immunoglobulins, were significantly and in some cases entirely dependent on TSLPR-dependent pathways. By contrast, the myeloid hyperplasia and reduced B cell levels in the bone marrow of Rabgef1 $1^{-1-}$ mice developed independently of the expression of TSLPR. While the mechanisms by which TSLPR signaling contributes to the noncutaneous phenotypic abnormalities in Rabgef1 $1^{-1-}$ mice remain to be fully elucidated, both myeloid and B cells express TSLPR and can respond to TSLP. ${ }^{27}$

In conclusion, our findings show that RabGEF1 can critically regulate the homeostasis of the cutaneous and lymphohematopoietic systems and that one effect of RabGEF1 deficiency is to develop strikingly elevated levels of TSLP, but that only some of the phenotypic abnormalities observed in Rabgef1-1- mice depend on the TSLP/TSLPR signaling pathway. Indeed, the finding that Rabgef1 ${ }^{-1-}$ mice can develop striking epidermal hyperplasia and skin inflammation with increased numbers of mast cells in the absence of TSLPR-dependent signaling identifies a TSLP/TSLPR-independent mechanism for developing skin pathology with some of the features of "allergic type" cutaneous inflammation. Given some of the histological similarities between the chronic skin lesions which develop in Rabgef1 $1^{-1-}$ mice and those observed in atopic dermatitis and other chronic skin diseases in humans, we propose that Rabgef1 $1^{-1-}$ mice may be useful in revealing new insights into interactions between the cutaneous and immune systems which contribute to the development and progression of such skin disorders.

\section{Acknowledgments}

We thank Mariola Lieberabach and Chen Liu for technical assistance, Dr. Janet Kalesnikoff for critical reading of this manuscript, and Dr. Jean-Pierre Kinet for BALB/c-Fcer1a ${ }^{-1-}$ mice.

\section{References}

1. Leonard WJ: TSLP: finally in the limelight. Nat Immunol 2002 3:605-607

2. Soumelis V, Liu YJ: Human thymic stromal lymphopoietin: a nove epithelial cell-derived cytokine and a potential key player in the induction of allergic inflammation. Springer Semin Immunopathol 2004 25:325-333

3. Liu YJ, Soumelis V, Watanabe N, Ito T, Wang YH, Malefyt Rde W Omori M, Zhou B, Ziegler SF: TSLP: an epithelial cell cytokine that regulates $T$ cell differentiation by conditioning dendritic cell maturation. Annu Rev Immunol 2007, 25:193-219

4. Holgate ST: The epithelium takes centre stage in asthma and atopic dermatitis. Trends Immunol 2007, 28:248-251 
5. Wang YH, Liu YJ: Thymic stromal lymphopoietin. OX40-ligand, and interleukin-25 in allergic responses. Clin Exp Allergy 2009, 39:798-806

6. Ito T, Wang YH, Duramad O, Hori T, Delespesse GJ, Watanabe N, Qin FX, Yao Z, Cao W, Liu YJ: TSLP-activated dendritic cells induce an inflammatory T helper type 2 cell response through OX40 ligand. J Exp Med 2005, 202:1213-1223

7. Soumelis V, Reche PA, Kanzler H, Yuan W, Edward G, Homey B, Gilliet M, Ho S, Antonenko S, Lauerma A, Smith K, Gorman D, Zurawski S, Abrams J, Menon S, McClanahan T, de Waal-Malefyt Rd R, Bazan F, Kastelein RA, Liu YJ: Human epithelial cells trigger dendritic cell mediated allergic inflammation by producing TSLP. Nat Immunol 2002, 3:673-680

8. Huston DP, Liu YJ: Thymic stromal lymphopoietin:a potential therapeutic target for allergy and asthma. Curr Allergy Asthma Rep 2006, 6:372-376

9. Allakhverdi Z, Comeau MR, Jessup HK, Yoon BR, Brewer A, Chartier S, Paquette N, Ziegler SF, Sarfati M, Delespesse G: Thymic stromal lymphopoietin is released by human epithelial cells in response to microbes, trauma, or inflammation and potently activates mast cells. J Exp Med 2007, 204:253-258

10. Wong CK, Hu S, Cheung PF, Lam CW: Thymic stromal lymphopoietin induces chemotactic and pro-survival effects in eosinophils: Implications in allergic inflammation. Am J Respir Cell Mol Biol, 2010, 43:305-315

11. Li M, Messaddeq N, Teletin M, Pasquali JL, Metzger D, Chambon P: Retinoid $\mathrm{X}$ receptor ablation in adult mouse keratinocytes generates an atopic dermatitis triggered by thymic stromal lymphopoietin. Proc Natl Acad Sci USA 2005, 102:14795-14800

12. Yoo J, Omori M, Gyarmati D, Zhou B, Aye T, Brewer A, Comeau MR, Campbell DJ, Ziegler SF: Spontaneous atopic dermatitis in mice expressing an inducible thymic stromal lymphopoietin transgene specifically in the skin. J Exp Med 2005, 202:541-549

13. Zhang Z, Hener P, Frossard N, Kato S, Metzger D, Li M, Chambon P: Thymic stromal lymphopoietin overproduced by keratinocytes in mouse skin aggravates experimental asthma. Proc Natl Acad Sci USA 2009, 106:1536-1541

14. Demehri S, Morimoto M, Holtzman MJ, Kopan R: Skin-derived TSLP triggers progression from epidermal-barrier defects to asthma. PLoS Biol 2009, 7:e1000067

15. Tam SY, Tsai M, Snouwaert JN, Kalesnikoff J, Scherrer D, Nakae S, Chatterjea D, Bouley DM, Galli SJ: RabGEF1 is a negative regulator of mast cell activation and skin inflammation. Nat Immunol 2004 5:844-852

16. Kalesnikoff J, Rios EJ, Chen CC, Nakae S, Zabel BA, Butcher EC, Tsai M, Tam SY, Galli SJ: RabGEF1 regulates stem cell factor/c-Kit-mediated signaling events and biological responses in mast cells. Proc Natl Acad Sci USA 2006, 103:2659-2664

17. Kalesnikoff J, Rios EJ, Chen CC, Alejandro Barbieri M, Tsai M, Tam SY, Galli SJ: Roles of RabGEF1/Rabex-5 domains in regulating FC epsilon RI surface expression and Fc epsilon RI-dependent responses in mast cells. Blood 2007, 109:5308-5317

18. Zerial M, McBride $\mathrm{H}$ : Rab proteins as membrane organizers. Nat Rev Mol Cell Biol 2001, 2:107-117

19. Bucci C, Parton RG, Mather IH, Stunnenberg H, Simons K, Hoflack B, Zerial M: The small GTPase rab5 functions as a regulatory factor in the early endocytic pathway. Cell 1992, 70:715-728

20. Delprato A, Merithew E, Lambright DG: Structure, exchange determinants, and family-wide rab specificity of the tandem helical bundle and Vps9 domains of Rabex-5. Cell 2004, 118:607-617

21. Carpino N, Thierfelder WE, Chang MS, Saris C, Turner SJ, Ziegler SF, Ihle JN: Absence of an essential role for thymic stromal lymphopoietin receptor in murine B-cell development. Mol Cell Biol 2004, 24:2584-2592

22. Dombrowicz D, Flamand V, Brigman KK, Koller BH, Kinet JP: Abolition of anaphylaxis by targeted disruption of the high affinity immunoglobulin E receptor alpha chain gene. Cell 1993, 75:969-976

23. Kimura K, Song CH, Rastogi A, Dranoff G, Galli SJ, Lantz CS: Inter- leukin-3 and c-Kit/stem cell factor are required for normal eosinophil responses in mice infected with Strongyloides venezuelensis. Lab Invest 2006, 86:987-996

24. Grimbaldeston MA, Nakae S, Kalesnikoff J, Tsai M, Galli SJ: Mast cell-derived interleukin 10 limits skin pathology in contact dermatitis and chronic irradiation with ultraviolet B. Nat Immunol 2007, 8:1095-1104

25. Mombaerts $\mathrm{P}$, lacomini J, Johnson RS, Herrup $\mathrm{K}$, Tonegawa $\mathrm{S}$, Papaioannou VE: RAG-1-deficient mice have no mature $B$ and $T$ lymphocytes. Cell 1992, 68:869-877

26. Yu C, Cantor AB, Yang H, Browne C, Wells RA, Fujiwara Y, Orkin SH: Targeted deletion of a high-affinity GATA-binding site in the GATA-1 promoter leads to selective loss of the eosinophil lineage in vivo. J Exp Med 2002, 195:1387-1395

27. Astrakhan A, Omori M, Nguyen T, Becker-Herman S, Iseki M, Aye T, Hudkins K, Dooley J, Farr A, Alpers CE, Ziegler SF, Rawlings DJ: Local increase in thymic stromal lymphopoietin induces systemic alterations in B cell development. Nat Immunol 2007, 8:522-531

28. Bradley PP, Christensen RD, Rothstein G: Cellular and extracellular myeloperoxidase in pyogenic inflammation. Blood 1982, 60:618-622

29. Omori M, Ziegler S: Induction of IL-4 expression in CD4(+) T cells by thymic stromal lymphopoietin. J Immunol 2007, 178:1396-1404

30. Rochman I, Watanabe N, Arima K, Liu YJ, Leonard WJ: Cutting edge: direct action of thymic stromal lymphopoietin on activated human CD4+ T cells. J Immunol 2007, 178:6720-6724

31. Li M, Hener P, Zhang Z, Kato S, Metzger D, Chambon P: Topical vitamin D3 and low-calcemic analogs induce thymic stromal lymphopoietin in mouse keratinocytes and trigger an atopic dermatitis. Proc Natl Acad Sci USA 2006, 103:11736-11741

32. Humphreys NE, Xu D, Hepworth MR, Liew FY, Grencis RK: IL-33, a potent inducer of adaptive immunity to intestinal nematodes. J Immunol 2008, 180:2443-2449

33. Kato A, Favoreto S Jr, Avila PC, Schleimer RP: TLR3- and Th2 cytokine-dependent production of thymic stromal lymphopoietin in human airway epithelial cells. J Immunol 2007, 179:1080-1087

34. Lee HC, Headley MB, Iseki M, Ikuta K, Ziegler SF: Cutting edge: inhibition of NF-kappaB-mediated TSLP expression by retinoid $X$ receptor. J Immunol 2008, 181:5189-5193

35. Lee HC, Ziegler SF: Inducible expression of the proallergic cytokine thymic stromal lymphopoietin in airway epithelial cells is controlled by NFkappaB. Proc Natl Acad Sci USA 2007, 104:914-919

36. Okayama Y, Okumura S, Sagara H, Yuki K, Sasaki T, Watanabe N Fueki M, Sugiyama K, Takeda K, Fukuda T, Saito H, Ra C: FcepsilonRI-mediated thymic stromal lymphopoietin production by interleukin-4-primed human mast cells. Eur Respir J. 2009, 34:425-435

37. Sokol CL, Barton GM, Farr AG, Medzhitov R: A mechanism for the initiation of allergen-induced $\mathrm{T}$ helper type 2 responses. Nat Immunol 2008, 9:310-318

38. Zaph C, Troy AE, Taylor BC, Berman-Booty LD, Guild KJ, Du Y, Yost EA, Gruber AD, May MJ, Greten FR, Eckmann L, Karin M, Artis D: Epithelial-cell-intrinsic IKK-beta expression regulates intestinal immune homeostasis. Nature 2007, 446:552-556

39. Diatchenko L, Romanov S, Malinina I, Clarke J, Tchivilev I, Li X, Makarov SS: Identification of novel mediators of NF-kappaB through genome-wide survey of monocyte adherence-induced genes. J Leukoc Biol 2005, 78:1366-1377

40. Oyoshi MK, He R, Kumar L, Yoon J, Geha RS: Cellular and molecular mechanisms in atopic dermatitis. Adv Immunol 2009, 102:135-226

41. Kawakami T, Ando T, Kimura M, Wilson BS, Kawakami Y: Mast cells in atopic dermatitis. Curr Opin Immunol 2009, 21:666-678

42. He R, Oyoshi MK, Garibyan L, Kumar L, Ziegler SF, Geha RS: TSLP acts on infiltrating effector $T$ cells to drive allergic skin inflammation. Proc Natl Acad Sci USA 2008, 105:11875-11880

43. Jessup HK, Brewer AW, Omori M, Rickel EA, Budelsky AL, Yoon BR, Ziegler SF, Comeau MR: Intradermal administration of thymic stromal lymphopoietin induces a T cell- and eosinophil-dependent systemic Th2 inflammatory response. J Immunol 2008, 181:4311-4319 